\title{
Eye health promotion-oriented policy statements in various national and provincial health policy documents in South Africa
}

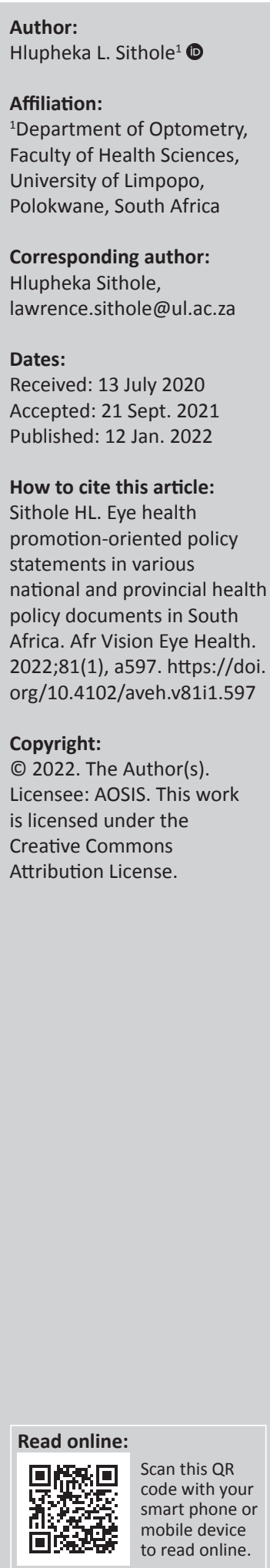

Background: There are many fragmented public health policies that give directives towards various aspects of healthcare needs and implementation. However, none of these policies make specific reference to eye health promotion (EHP) as an enabler for individuals to take control of the determinants of their eye health $(\mathrm{EH})$ needs.

Aim: The current study sought to identify EHP messages in the various available policy documents at both national and provincial health department levels with a view to assessing awareness on the available gaps for the development of an integrated EHP policy in South Africa.

Setting: The study used documents provided by the National Department of Health and those that were available online from various other provincial Departments of Health in the country.

Methods: Content analysis of EH policies requested from the Directorate of Chronic Diseases, Disabilities and Geriatrics was conducted. Various other health policies that were enacted post-1994 and endorsed by the National and Provincial Departments of Health were also considered for analysis.

Results: Twenty-four documents were considered for content analysis. The national guidelines on eye healthcare made reference to $\mathrm{EH}$ activities such as immunisation of children, vision screening of the elderly, vitamin A supplementation and maternal services to detect sexually transmitted diseases, amongst others. Of the 20 national and provincial health documents analysed, only four made reference to $\mathrm{EH}$. None of these documents made any specific reference to EHP.

Conclusion: Although four national guidelines contain content related to EHP, the fragmentation and lack of integration with other health policy documents may lead to eye healthcare messages not being prioritised for dissemination even where they are highly required. Also, public eye healthcare services in general will continue to lag behind as is the case in most provinces in South Africa.

Keywords: eye health promotion; eye healthcare policy; integration of eye healthcare policies; health promotion messages; national eye health guidelines.

\section{Introduction}

The Universal Eye Health: A Global Action Plan (2014-2019), articulated the essence of eliminating unwarranted cases of blindness through the participation of member states by developing and implementing favourable policies. ${ }^{1}$ The importance of developing health policies that expedite and advocate for considerations for healthcare needs of people in the developing countries is of vital importance. These policies have to be implemented as part of the health systems that are aimed at improving the lives of individual community members in those countries. According to Han, ${ }^{2}$ the 2000 World Health Report pointed out three fundamental objectives of health systems, namely improving the health of the populations they serve, responding to people's expectations and providing financial protection against costs because of illness. Unfortunately, health systems in developing countries are constantly exposed to challenges occurring as a result of epidemiological diversity and urbanisation within uneven but rapid economic growth in some instances. ${ }^{3,4,5}$ Demographic changes, massive urbanisation, rural environments and the advent of unhealthy lifestyles have resulted in rapidly changing disease patterns on a global level since the industrial revolution of the 18th century, ${ }^{6}$ and this appears to be the case even in South Africa. In view of these developments and conventional patterns of disease processes as well as challenges that are inherent in the developmental landscape of South Africa, all health disciplines, including 
those that focus on eye care services should be considered in all health policy developments.

According to Bennett et al., ${ }^{7}$ developing a strong health policy may influence health outcomes of the population. In support of this assertion, Filmer et al. ${ }^{8}$ argued that although health policy development appears to focus on preventive versus curative services, there is a need to develop health policies that respond best to health priorities within the prevailing political, social and economic influences that impact health and service provisions. In agreement with this view, Jamison and Mosley's ${ }^{9}$ arguments for strategies in health policy development have important implications. The authors postulated that whilst there is a need for health priority assessment on a national level, there is also a need to translate national health priorities to a local epidemiological context with consideration being given to the socio-cultural, administrative, economic and political impact on healthcare. It is, therefore, imperative that health policy strategies address issues on equity, efficiency, acceptability and sustainability within health service provision. ${ }^{10,11}$ By extension, health issues that affect the delivery of eye care services should also be considered in policy development within the context of urban and rural communities. If this is done, the burden of eye diseases such as cataract, glaucoma and blinding uncorrected refractive errors that have already been widely reported by various scholars will be adequately addressed. Unfortunately, there appears to be no political will to incorporate eye healthcare in the primary health care (PHC) system in South Africa, with much needed services being pooled in hospitals rather than local clinics and community health centres (CHCs).

Interestingly, there is a worldwide increasing awareness that the underlying determinants of eye diseases are intricately influenced by those that also affect the well-being of individuals. ${ }^{12,13}$ This refers to the social determinants of health which are directly linked to the environment within which affected individuals are born, grow and work. ${ }^{14}$ It is therefore important that health policy development considers this very intricate relationship between the social determinants of health and eye health (EH) and the factors that link eye diseases to ill-health. Whilst health policy development is essentially considered a political process, this inter-relationship between $\mathrm{EH}$ and general health has important implications for eye health promotion (EHP) and implementation of policy directives in South Africa. The focus on EHP usually portrays government's commitment to incorporating EH into the PHC system of the country through a political process that this seemingly easy process has become. The narrative of optometrists performing certain clinical duties that are viewed to be in the domain of ophthalmologists gives credence to the politics of EHP and the non-existent policy. Therefore, this study sought to analyse various accessible health policy documents with a view to identifying statements that made specific reference to the importance of EHP in the country, which may cast a light on the determination of authorities to incorporate $\mathrm{EH}$ into PHC system in South Africa.

\section{Methodology}

Content analysis by means of a qualitative research approach was used for this study. The purpose of content analysis is to organise and elicit meaning from the document being analysed and draw realistic conclusions from it. ${ }^{15}$ As a result, policies on $\mathrm{EH}$ were requested from the Directorate of Chronic Diseases, Disabilities and Geriatrics, after which national guidelines on the management of various eye healthcare conditions were provided. Also, national and provincial general health policies were sought in the websites of both the national and provincial health departments across all nine provinces of South Africa using Google search engine. Search words such as health promotion, eye health promotion and integrated eye health policy were used during the search for information. Only documents relevant to the purpose of the study were considered for analysis and interpretation. The criterion used in the selection of the health policy documents was that the document must have been produced by the Department of Health or endorsed by the Department of Health in South Africa. Also, only health documents produced in the post-apartheid era were considered for analysis. This was done to eliminate documents that might have had polarisation towards specific groups of people during apartheid than the ones that may be perceived to be more inclusive post-apartheid. Also, the type of $\mathrm{EH}$ promotional messages may have changed over time because of epidemiological transitions. The study received ethical approval from the University of South Africa's Department of Health Studies before commencement. Permission was also received from the National Department of Health to conduct the study throughout the country.

\section{Eye health documents analysis}

The research focused on specific evidence-based findings that have been proven to be capable of contributing towards improvements in community EH in a cost-effective manner. To this end, the initial stage in EH policy analysis involved locating EHP elements in policy statements contained in the provided national guidelines on EH matters. Thereafter, the second stage sought and also examined the context in which EHP is expressed. The analysis process attempted to identify potential recipients of the programmes or interventions, human resources and levels of care and service provision. The third stage of the analysis process was to determine if there was a rational and scientific basis for the selection of EHP needs, priorities and strategies. The criteria for $\mathrm{EH}$ needs assessment looked at epidemiological prevalence, impact on health resources, community well-being, and whether health priorities or needs were localised or population-wide. Any possible proposals on EHP strategies and interventions were critically compared with the published evidence-based literature before inclusion.

\section{General health policy analysis}

The research developed a common set of criteria that was systematically applied to the documents analysed. 
General health policy content analysis was also conducted in stages. The stages involved identification of statements on EHP in the general health policy documents. If EH or EHP was mentioned in policy statements, then the analytical process proceeded to determine if there was a rational or scientific basis to the selection of these strategies. If EH was not mentioned in policy documents, then the next stage would be to identify the provision for lifestyle induced risk factors. The analytical process attempted to determine if EHP could be incorporated into the lifestyle induced risk factor element in health policy documents.

\section{Ethical considerations}

The study received ethical clearance from the Research Ethics Committee of the Department of Health Studies at the University of South Africa before the commencement of the study (reference number: 45962545).

\section{Results}

A total of 24 documents from the national and provincial health departments were obtained for content analysis. Amongst these, four were guidelines on $\mathrm{EH}$ management protocols and the rest (20) were generic health policy documents. In order to understand the position and commitment of health authorities on matters of EHP, the following analysis was made.

\section{Locating eye health promotion statements in eye health policy documents}

The Directorate of Chronic Diseases, Disabilities and Geriatrics in which EHP activities were planned provided the following guidelines which were their only documents on $\mathrm{EH}$ in general:

\section{National guideline on prevention of blindness in South Africa}

The national guideline on prevention of blindness in South Africa is a document that focuses on the prevention of avoidable blindness as a component of the VISION 2020 global initiative. It focuses on the prevention of diseases and has set out four levels of prevention which may be interpreted as a strategy for EHP. Its analysis was done in line with the questions and evidence as shown in Table 1.

\section{National guideline on the management and control of eye conditions at primary level}

The objectives of this guideline are to effectively manage eye conditions at primary level thereby limiting complications and potential blindness. It further seeks to apply costeffective interventions and accessibility to eye care for persons with eye disease/problems. In order to determine its
TABLE 1: Analysis of the guideline on prevention of blindness in South Africa.

\begin{tabular}{|c|c|c|}
\hline Questions & Evidence for health promotion & Scientific basis \\
\hline $\begin{array}{l}\text { What are the } \\
\text { proposals for EHP? }\end{array}$ & $\begin{array}{l}\text { - Health education } \\
\text { - Immunisation } \\
\text { - Maternal services to } \\
\text { detect STDs } \\
\text { - Eye safety promotion }\end{array}$ & $\begin{array}{l}\text { The Ottawa Charter }{ }^{14} \text { and } \\
\text { literature supports the } \\
\text { selection of these initiatives }\end{array}$ \\
\hline $\begin{array}{l}\text { Who is the target } \\
\text { population for the } \\
\text { policy narrative? }\end{array}$ & $\begin{array}{l}\text { - General population for } \\
\text { health education issues } \\
\text { - Children between } 0 \text { and } 11 \\
\text { years for immunisation } \\
\text { - Expectant mothers for } \\
\text { maternal services } \\
\text { - Workforce in industries for } \\
\text { eye protection }\end{array}$ & - \\
\hline
\end{tabular}

STDs, Sexually transmitted diseases; EHP, eye health promotion.

TABLE 2: Analysis of the guideline on management and control of eye conditions at primary level.

\begin{tabular}{lll}
\hline Question & $\begin{array}{l}\text { Evidence for health } \\
\text { promotion }\end{array}$ & Scientific basis \\
\hline $\begin{array}{l}\text { What are the proposals } \\
\text { for EHP? }\end{array}$ & $\begin{array}{l}\text { Vitamin A } \\
\text { supplementation } \\
\text { - Education on personal } \\
\text { hygiene }\end{array}$ & $\begin{array}{l}\text { The Ottawa Charter }{ }^{14} \text { and } \\
\text { literature supports the } \\
\text { selection of these initiatives }\end{array}$ \\
& Maternal services to \\
& detect STDs & \\
Who is the target & - School going children for & - \\
population for the & Vitamin A & \\
policy narrative? & $\begin{array}{l}\text { General population for } \\
\text { hygiene practices }\end{array}$ & \\
& Expectant mothers for & \\
& maternal services & \\
\hline
\end{tabular}

STDs, Sexually transmitted diseases; EHP, eye health promotion.

TABLE 3: Analysis of the guideline on refractive errors screening for persons 60 years and older.

\begin{tabular}{|c|c|c|}
\hline Question & Evidence for health promotion $S$ & Scientific basis \\
\hline $\begin{array}{l}\text { What are the } \\
\text { proposals for EHP? }\end{array}$ & $\begin{array}{l}\text { - Provision of vision screening } \\
\text { exercises } \\
\text { - Provision of refractive } \\
\text { services } \\
\text { - Provision of spectacles }\end{array}$ & $\begin{array}{l}\text { The Ottawa Charter }{ }^{14} \text { and } \\
\text { literature supports the } \\
\text { selection of these initiatives }\end{array}$ \\
\hline $\begin{array}{l}\text { Who is the target } \\
\text { population for the } \\
\text { policy narrative? }\end{array}$ & $\begin{array}{l}\text { - Vision screening targeted for - } \\
\text { persons } 60 \text { years and older } \\
\text { - Refraction for persons } 60 \\
\text { years and older only } \\
\text { - Provision of spectacles for the } \\
\text { same age group }\end{array}$ & \\
\hline
\end{tabular}

EHP, eye health promotion.

relevance and focus to EHP, the questions and evidence as presented in Table 2 were recorded.

\section{National guideline on refractive error screening for persons 60 years and older}

The objectives of this guideline include the identification, referral and provision of services for the targeted adults who may benefit from refractive correction by provision of screening services, provision of refractive services, provision of cost-effective correction devices, establishment of appropriate referral channels and establishment of estimates of refractive errors needs for the targeted population. The focus on EHP promotion is shown in Table 3.

\section{National guideline on cataract surgery}

The objectives of these guidelines include to correct blindness and impaired vision, to reduce the economic burden to the individual, family and community and to improve the quality of life of the individual. The focus on EHP is shown in Table 4. 


\section{Locating eye health promotion related messages in other health documents \\ National and provincial health policy analysis}

The national documents that were analysed include, amongst others, the constitution of the Republic of South Africa, National School Health policy and Integrated Nutrition Programme. The rest of the documents are as shown in Table 5. Analysis of national health policy documents revealed that only four documents, namely, the District Hospital Service Package for South Africa, National School Health Policy, Integrated Nutrition Programme and Comprehensive Primary Health Care Package, had statements that referred to EH. At provincial level, only the Comprehensive Primary Health Care document made mention of EH. Other documents analysed are shown in Table 6. All documents analysed made no mention of EHP.

\section{Discussion}

Eye health promotion is an important aspect of any action plan that seeks to address causative factors of various forms of visual impairment and blindness. The national guidelines

\begin{tabular}{|c|c|c|}
\hline Question & Evidence & Scientific basis \\
\hline $\begin{array}{l}\text { What are the } \\
\text { proposals for EHP? }\end{array}$ & $\begin{array}{l}\text { - Marketing cataract surgery } \\
\text { - Information on availability and } \\
\text { success of cataract surgery } \\
\text { - Case detectors }\end{array}$ & $\begin{array}{l}\text { The Ottawa Charter }{ }^{14} \text { and } \\
\text { literature supports the } \\
\text { selection of these initiatives }\end{array}$ \\
\hline $\begin{array}{l}\text { Who is the target } \\
\text { population for the } \\
\text { policy narrative? }\end{array}$ & $\begin{array}{l}\text { - Cataract surgery for all } \\
\text { patients needing such a service } \\
\text { - General public attending public } \\
\text { hospitals to be informed of } \\
\text { availability of services } \\
\text { - Children and school teachers } \\
\text { undergoing vision screening to } \\
\text { be used a community case } \\
\text { detectors }\end{array}$ & - \\
\hline
\end{tabular}

EHP, eye health promotion. on various ways of addressing visual ailments by members of the public should be considered as an important baseline in policy development. Although none of these documents make mention of EHP specifically, or reference to issues such as health education, immunisation, safety promotion and maternal services in the national guideline on prevention of blindness in South Africa has a direct contribution to issues of EHP. For example, a study by Khanna ${ }^{16}$ highlighted the importance of health education through school health integrated programmes that target school-going children. In this study, the author made reference to the Indian government by way of acknowledging the commitment made by recognising the importance of $\mathrm{EH}$ care programmes within the schools. Similarly, the South African government has also recognised the importance of integrated school health programmes that encompass early childhood vision screening programmes in the primary schools. ${ }^{17}$ Furthermore, the guideline considers immunisation as an important initiative for eliminating unwarranted causes of visual impairment and blindness and this has also been integrated in the school health programmes. This is a commendable initiative as causes of blindness, especially amongst children, can be prevented through immunisation programmes against measles and vitamin A supplementation that can assist in the eradication of diseases such as exophthalmia and corneal scarring that may lead to avoidable blindness.

Vitamin A supplementation has also been mentioned in the second guideline on the management and control of eye conditions at primary level with a view to alerting eye healthcare practitioners on the need for this control measure in the prevention of childhood blindness. Undiagnosed and uncorrected causes of visual impairment in childhood can negatively affect the development of vision and cause learners to have low academic success or even quit

TABLE 5: National policy documents considered for analysis.

\begin{tabular}{|c|c|c|c|c|c|c|c|}
\hline Policy No. & Reference document & Is EH mentioned? & Is EHP mentioned? & Is context mentioned? & Scientific basis & $\begin{array}{l}\text { Risk factor/HP } \\
\text { mentioned }\end{array}$ & $\begin{array}{l}\text { Where can EHP be } \\
\text { incorporated? }\end{array}$ \\
\hline 1. & $\begin{array}{l}\text { Republic of South Africa } \\
\text { Constitution }\end{array}$ & No & No & None & None & None & $\begin{array}{l}\text { Health promotion, } \\
\text { nutrition }\end{array}$ \\
\hline 2. & National Bill of Health & No & No & None & None & None & $\begin{array}{l}\text { Health promotion, } \\
\text { nutrition }\end{array}$ \\
\hline 4. & $\begin{array}{l}\text { A District Hospital Service } \\
\text { Package for South Africa }\end{array}$ & Yes & No & None & No & $\begin{array}{l}\text { Education, health } \\
\text { promotion }\end{array}$ & Within PHC training \\
\hline 5. & $\begin{array}{l}\text { National School Health } \\
\text { Policy }\end{array}$ & Yes & No & None & No & $\begin{array}{l}\text { Education, life skills, } \\
\text { health promotion }\end{array}$ & $\begin{array}{l}\text { Health promotion, } \\
\text { school health, PHC }\end{array}$ \\
\hline 6. & $\begin{array}{l}\text { Integrated Nutrition } \\
\text { Programme }\end{array}$ & Yes & No & $\begin{array}{l}\text { Priorities for children and } \\
\text { all post-partum women }\end{array}$ & Yes & Health promotion & School health, PHC \\
\hline 7. & $\begin{array}{l}\text { Comprehensive Primary } \\
\text { Health Care Package }\end{array}$ & Yes & No & None & No & $\begin{array}{l}\text { Education, exercise, } \\
\text { nutrition }\end{array}$ & $\begin{array}{l}\text { PHC, school health } \\
\text { programme }\end{array}$ \\
\hline 8. & MCWH & No & No & None & No & Nutrition & Health education, PHC \\
\hline 9. & $\begin{array}{l}\text { HIV/AIDS/STD Strategic } \\
\text { Plan for South Africa }\end{array}$ & No & No & None & No & Nutrition & Health promotion, $\mathrm{PHC}$ \\
\hline 10. & $\begin{array}{l}\text { Youth and Adolescent } \\
\text { Health }\end{array}$ & No & No & None & No & Life skills & $\begin{array}{l}\text { Health promotion, PHC, } \\
\text { school health, } \\
\text { occupational settings }\end{array}$ \\
\hline 11. & Bill of Rights & No & No & None & No & Health promotion & All levels of care \\
\hline 12. & $\begin{array}{l}\text { Department of Higher } \\
\text { Education South Africa } \\
\text { Health survey }\end{array}$ & No & No & None & No & Health promotion & All levels of care \\
\hline 13. & RDP, National Health Plan & No & No & None & No & None & PHC, health promotion \\
\hline
\end{tabular}

$\mathrm{EH}$, eye health; HP, health promotion; EHP, eye health promotion; MCWH, Maternal, Child and Women's Health; HIV/AIDS/STD, human immunodeficiency virus/acquired immunodeficiency syndrome/sexually transmitted disease; RDP, Reconstruction and Development Programme; PHC, primary health care. 
TABLE 6: Provincial level documents obtained for analysis.

\begin{tabular}{|c|c|c|c|c|c|c|c|}
\hline $\begin{array}{l}\text { Policy } \\
\text { No. }\end{array}$ & Reference document & Is EH mentioned? & Is EHP mentioned? & $\begin{array}{l}\text { Is context } \\
\text { mentioned? }\end{array}$ & Scientific basis & $\begin{array}{l}\text { Risk factor/HP } \\
\text { mentioned }\end{array}$ & $\begin{array}{l}\text { Where can EHP be } \\
\text { incorporated? }\end{array}$ \\
\hline 1. & Ottawa Charter (1986) & No & No & None & None & None & $\begin{array}{l}\text { Health promotion, } \\
\text { nutrition }\end{array}$ \\
\hline 2. & National School Health Policy & Yes & No & None & No & $\begin{array}{l}\text { Education, life skills, } \\
\text { health promotion }\end{array}$ & $\begin{array}{l}\text { Health promotion, } \\
\text { school health, } \mathrm{PHC}\end{array}$ \\
\hline 3. & $\begin{array}{l}\text { Integrated Nutrition } \\
\text { Programme }\end{array}$ & Yes & No & $\begin{array}{l}\text { Priorities for children } \\
\text { and all post-partum } \\
\text { women }\end{array}$ & Yes & Health promotion & School health, PHC \\
\hline 4. & $\begin{array}{l}\text { Comprehensive Primary } \\
\text { Health care Package }\end{array}$ & Yes & No & None & No & $\begin{array}{l}\text { Education, exercise, } \\
\text { nutrition }\end{array}$ & $\begin{array}{l}\text { PHC, school health } \\
\text { programme }\end{array}$ \\
\hline 5. & $\begin{array}{l}\text { Primary Health care in } \\
\text { Mpumalanga }\end{array}$ & No & No & None & No & Nutrition & Health education, $\mathrm{PHC}$ \\
\hline 6. & Bill of Rights & No & No & None & No & Health promotion & All levels of care \\
\hline 7. & RDP, National Health Plan & No & No & None & No & None & $\begin{array}{l}\text { PHC, health } \\
\text { promotion }\end{array}$ \\
\hline
\end{tabular}

$\mathrm{EH}$, eye health; HP, health promotion; EHP, eye health promotion; RDP, Reconstruction and Development Programme; PHC, primary health care.

school before graduation. ${ }^{18}$ Malik et al. ${ }^{19}$ recommended various key activities to promote good $\mathrm{EH}$, especially in children, these are shown in Table $7 .^{18}$

The guideline also makes reference to the importance of maternal health services as an important strategy in the elimination of EH diseases. Notably, ophthalmic neonatorum affects children in the first few weeks after birth and this infection is usually contracted during delivery, ${ }^{20}$ and such a disease can be avoided when precautionary measures are taken during maternal health services. Although maternal health services are freely available for expectant mothers in South Africa, there appears to be those who do not use these services, thus putting the life of the new born at risk of developing infectious diseases. ${ }^{21,22}$ There is therefore a need for creating awareness about the need for antenatal care services amongst expectant mothers in order to avoid any possible EH problems when a child is born.

Another important element mentioned in the national guideline on prevention of blindness in South Africa is the promotion of eye safety. Although there are no educational and preventive programmes on eye protection especially in industries that have the propensity to cause irreversible eye damage, ${ }^{23}$ workplace eye injuries remain a common occurrence in South Africa. ${ }^{24}$ Eye protection awareness campaigns should be initiated by relevant authorities across South Africa to eliminate avoidable eye injuries that may cause irreversible blindness.

The World Health Organisation (WHO) promotes the washing of faces in the global initiative to eliminate trachoma through the Surgery, Antibiotics, Facial cleanliness and Environmental improvements (SAFE) strategy by the year 2020.25 This strategy advocates for the use of antibiotics for treating trachoma, management of trichiasis through surgery, considerations for environmental improvements through the provision of sanitation and clean water in the household as well as facial cleanliness for reducing transmissions. ${ }^{26,27}$ Although the disease was prevalent in the early eighties in the former northern Transvaal region (now Limpopo Province) of South Africa, affecting mostly children, ${ }^{28}$ it is now widely believed that the disease has been eliminated in South Africa. However, it remains a leading infectious disease that cause
TABLE 7: Ten key activities for the prevention of visual impairment in children.

\begin{tabular}{|c|c|}
\hline Eye conditions & Management \\
\hline \multicolumn{2}{|c|}{ Control of conditions that can be associated with visual impairment } \\
\hline Vitamin A deficiency & $\begin{array}{l}\text { - Routine administration of Vitamin A } \\
\text { - Mothers to be given Vitamin A also } \\
\text { following delivery } \\
\text { - Breast feeding and good nutrition to } \\
\text { be encouraged }\end{array}$ \\
\hline Measles & $\begin{array}{l}\text { - Provide Vitamin A supplements to children } \\
\text { with measles or malnutrition } \\
\text { - Immunisation of children against measles }\end{array}$ \\
\hline \multicolumn{2}{|l|}{ Control of ocular conditions } \\
\hline Conjunctivitis of the new born & $\begin{array}{l}\text { - Baby eyes to be cleaned after birth and } \\
\text { antibiotic drops be applied }\end{array}$ \\
\hline Trachoma & - Children's faces to be kept clean \\
\hline $\begin{array}{l}\text { Cataract/retinoblastoma/ocular } \\
\text { abnormalities }\end{array}$ & $\begin{array}{l}\text { - Children with white pupils and poor vision } \\
\text { to be referred to an eye healthcare } \\
\text { professional }\end{array}$ \\
\hline TEM & - The use of TEM to be avoided \\
\hline Blunt eye trauma & $\begin{array}{l}\text { - Children with history of eye injuries to be } \\
\text { referred to an eye healthcare professional }\end{array}$ \\
\hline
\end{tabular}

Source: Adapted from Malik NJ, Mafwiri M, Gilbert C. Integrating primary eye care into global child health policies. Arch Dis Child. 2018;103(2):176-180. https://doi.org/10.1136/ archdischild-2017-313536

TEM, traditional eye medicine.

blindness amongst children and adults in most parts of the world including the African continent. ${ }^{29}$ Notably, the second guideline refers to issues of personal hygiene, which is a contributory factor in the contraction of trachoma. Therefore, face washing should be promoted at all times, especially during these times of Corona Virus 2019 disease (COVID-19).

Although the prevalence of the uncorrected refractive error was found to be relatively low amongst South Africans,,$^{30}$ an earlier study that examined 4890 school-going children found that $63.6 \%$ of the 91 eyes examined had reduced vision. ${ }^{31}$ Another study conducted in three communities amongst individuals aged 16-74 years in the Western Cape Province revealed that $30.8 \%$ of the participants had refractive error. ${ }^{32}$ This shows that there is a need for vision screening programmes for early detection of any eye conditions that may cause visual impairment or blindness if left unattended. Therefore, the activities of vision screening, refraction services and provision of spectacles mentioned in the guideline on refractive errors screening for persons 60 years and older may be considered to be efforts for effective EHP for this age group. However, vision screening exercises for this age group should also focus on other eye diseases that cause visual impairment and blindness 
amongst the elderly for timeous intervention. In a study by Maake and Oduntan ${ }^{33}$ on the prevalence and causes of visual impairment amongst patients seen at Khensani Hospital in Giyani, it was found that cataract (34.1\%) and glaucoma $(31.7 \%)$ were the leading causes of blindness whilst uncorrected refractive errors $(56.7 \%)$ were the leading cause of low vision. That the last guideline makes reference to cataract surgery, and advertising such services to those who need them can be considered an important EHP message. As alluded to in a study by Khoza et al., ${ }^{34}$ which was a survey on the prevalence of cataract in the selected communities of the Limpopo Province, such references to cataract surgery as mentioned in the guideline on cataract surgery should be supported by improved accessibility to cataract surgery services. Barriers to accessibility to cataract surgery are a major contributory factor to the scourge of blindness because of cataract.

In other documents that were found on the websites of the national and provincial departments of health that made mention to $\mathrm{EH}$, the focus was mainly on vision screening as an important message for health promotion. Upon analysis, these documents revealed that the aspects of good health cannot just be imposed on individuals, but involvement in the determinants of their health is of paramount importance. According to DiClemente and Kaczynski, ${ }^{35}$ understanding human behaviour is such a daunting challenge to an extent that if one is to implement the directives of the Ottawa Charter ${ }^{16}$ for effective $\mathrm{EH}$, there is a need to fully understand the theoretical models that can better predict the impact and outcomes of any intervention strategies. One such example is the ecological approach and models that provide a comprehensive framework for understanding human behaviour ${ }^{36}$ by studying levels of behavioural influence including psychological underpinnings, social and cultural beliefs, as well as their physical environment.

\section{Conclusion}

The content of the national guidelines on aspects of eye healthcare management in South Africa makes reference to important issues that relate to EHP in the country. Although there is still no integrated policy on EHP, statements such as face washing, immunisation, vision screening and cataract referrals make these documents to be important reference material for EHP initiatives in the country. In line with the directives of the Ottawa Charter, it was expected that there would be integration of EHP initiatives with most documents from the social sector cluster, however, this is not the case at both national and provincial levels as there appears to be no integration except at elementary school level where the policy on school health makes reference to such an integration. This further strengthens the call for the completion of the process of finalising the development of a stand-alone policy on eye healthcare that will ensure uniformity of EHP messages across all the provinces in South Africa.

\section{Acknowledgements Competing interests}

The author declares that there are no financial or personal relationships that may have inappropriately influenced the writing of this article.

\section{Author's contributions}

I declare that I am the sole author of this research article.

\section{Funding information}

This research received funding from the University of South Africa's Research Directorate and the National Research Foundation.

\section{Data availability}

Data sharing is not applicable to this article.

\section{Disclaimer}

The views and opinions expressed in this article are those of the author and do not necessarily reflect the official policy or position of any affiliated agency of the author, and the publisher.

\section{References}

1. World H Organisation. Universal eye health: A global action plan 2014-2019 [homepage on the Internet]. [cited $2021 \mathrm{Mar} 12$ ]. Available from: https://www. vision2020australia.org.au/wpcontent/uploads/2019/06/Universal-Eye-HealthA-Global-Action-Plan-2014-2019.pdf

2. Han W. Health care systems reforms in developing countries. J Public Health Res 2012;1(3):199-207. https://doi.org/10.4081/jphr.2012.e31

3. Maunder EMW, Matji J, Hlatshwayo-Molea T. Enjoy a variety of foods - Difficult but necessary in developing countries. S Afr J Comm Nutr. 2001;14:7-11.

4. Li X, Song J, Lin, T, et al. Urbanization and health in China, thinking at the national, local and individual levels. Environ Health. 2016;15:S32. https://doi.org/10.1186/ s12940-016-0104-5

5. Aliyu A, Amadu L. Urbanization, cities, and health: The challenges to Nigeria - A review. Ann Afr Med. 2017;16(4):149-158. https://doi.org/10.4103/aam. aam_1_17

6. Neiderud C. How urbanization affects the epidemiology of emerging infectious diseases. Infect Ecol Epidemiol. 2015;5(1). https://doi.org/10.3402/iee.v5.27060

7. Bennett S, Frenk J, Mills A. The evolution of the field of Health Policy and Systems Research and outstanding challenges. Health Res Policy Sys. 2018;16:43. https:// doi.org/10.1186/s12961-018-0317-x

8. Filmer D, Jeffrey $S$, Pritchett LA. Weak links in The Chain II: A prescription for health policy in poor countries. World Bank Res Obs. 2002;17(1):47-66. https:// doi.org/10.1093/wbro/17.1.47

9. Jamison DT, Mosley WH. Disease control priorities in developing countries: Health policy responses to epidemiological change. Am J Pub Health. 1991;81(1):15-22. https://doi.org/10.2105/AJPH.81.1.15

10. Kabene SM, Orchard C, Howard JM, et al. The importance of human resources management in health care: A global context. Hum Resour Health. 2006;4:20. https://doi.org/10.1186/1478-4491-4-20

11. Benatar S, Sullivan T, Brown A. Why equity in health and in access to health care are elusive: Insights from Canada and South Africa. Glob Public Health 2018;13(11):1533-1557. https://doi.org/10.1080/17441692.2017.1407813

12. Wang G, Bai Z, Shi J, et al. Prevalence and risk factors for eye diseases, blindness, and low vision in Lhasa, Tibet. Int J Ophthalmol. 2013;6(2):237-241. https://doi. org/10.3980/j.issn.2222-3959.2013.02.24

13. Islam FMA, Chakrabarti R, Islam SZ, et al. Factors associated with awareness, attitudes and practices regarding common eye diseases in the general population in a rural district in Bangladesh: The Bangladesh Population-based Diabetes and Eye Study (BPDES). PLoS One. 2015;10:e0133043. https://doi.org/10.1371/ journal.pone.0133043 
14. Braveman P, Gottlieb L. The social determinants of health: Its time to consider the causes of the causes. Public Health Rep, 2014 Jan-Feb:129(Suppl 2):19-31. https://doi.org/10.1177/00333549141291S206

15. Bengtsson M. How to plan and perform a qualitative study using content analysis NursingPlus Open. 2016;2:8-14. https://doi.org/10.1016/j.npls.2016.01.001

16. Khanna RC. Importance of integrating eye health into school health initiatives. Community Eye Health J. 2018;30(98):S3-S5.

17. South African National Department of Health. Integrated school health programmes [homepage on the Internet]. 4th DRAFT: ISHP resource manual fo SHN April 2012. [cited 2020 Jul 8]. Available from: http://www.section27.org.za/ wpcontent/uploads/2013/01/IntSchoolHealthProg.pdf

18. Kirag N, Temel AB. The effect of an eye health promotion program on the health protective behaviors of primary school students. J Educ Health Promot. 2018;7:37. https://doi.org/10.4103/jehp.jehp_67_17

19. Malik NJ, Mafwiri M, Gilbert C. Integrating primary eye care into global child health policies. Arch Dis Child. 2018;103(2):176-180. https://doi.org/10.1136/ archdischild-2017-313536

20. Jin J. Prevention of gonococcal eye infection in newborns. JAMA. 2019;321:414 https://doi.org/10.1001/jama.2018.21434

21. Susuman AS. Health care service and maternal education in South Africa. Scand J Public Health. 2015;43(7):673-676. https://doi.org/10.1177/140349481559 6501

22. Sithole HL. A situational analysis of ocular health promotion in the South African primary health-care system. Clin Exp Optom. 2017;100(2):167-173. https://doi. org/10.1111/cxo.12452

23. Sithole HL, Oduntan OA, Oriowo MO. Eye protection practices and symptoms among welders in the Limpopo Province of South Africa. S Afr Optom. 2009;68(3):130-136. https://doi.org/10.4102/aveh.v68i3.163

24. Sukati VN. Workplace eye injuries: A literature review. Occup Health South Afr. 2014;20:18-22.

25. Bailey R, Lietman T. The SAFE strategy for the elimination of trachoma by 2020 Will it work? Bull World Health Organ. 2001;79:233-236.
26. World Health Organization. Report of the seventh meeting of the WHO alliance for the global elimination of blinding trachoma [homepage on the Internet]. Geneva; 6-8 January 2003 [cited 2020 Jul 6]. Available from: www.who.int/pbd/ trachoma/Reports/reports.htm

27. Ejere HOD, Alhassan MB, Rabiu M. Face washing promotion for preventing active trachoma. Cochrane Database Syst Rev. 2015;4:CD003659. https://doi.org/10.1002/ 14651858.CD003659.pub3

28. Ballard RC, Fehler HG, Fotheringham $P$, et al. Trachoma in South Africa. Soc Sci Med. 1983;17(22):1755-1765. https://doi.org/10.1016/0277-9536(83)90388-X

29. Burton MJ, Mabey DCW. The global burden of trachoma: A review. PLoS Negl Trop Dis. 2009 Oct;3(10):e460. https://doi.org/10.1371/journal.pntd.0000460

30. Naidoo KS, Chinanayi FS, Ramson P, et al. Rapid assessment of refractive error in the eThekwini Municipality of KwaZulu-Natal, Durban, South Africa. Clin Exp Optom. 2016;99:360365. https://doi.org/10.1111/cxo.12377

31. Naidoo KS, Raghunandan A, Mashige KP, et al. Refractive error and visual impairment in African children in South Africa. Invest Ophthalmol Vis Sci. 2003;44(9):3764-3770. https://doi.org/10.1167/iovs.03-0283

32. Otutu M, Nachega J, Harvey J, et al. The prevalence of refractive error in three communities of Cape Town, South Africa. S Afr Optom. 2012;71(1):32-38. https:// doi.org/10.4102/aveh.v71i1.65

33. Maake MM, Oduntan O. Prevalence and causes of visual impairment in patients seen at Nkhensani Hospital Eye Clinic, South Africa. Afr J Prim Health Care Fam Med. 2015;7:728. https://doi.org/10.4102/phcfm.v7i1.728

34. Khoza LB, Nunu WN, Tshivhase SE, et al. Survey on prevalence of cataract in selected communities in Limpopo Province of South Africa. Sci Afr. 2020;8:e0035. https://doi.org/10.1016/j.sciaf.2020.e00352

35. DiClemente RJ, Kaczynski JM. The importance of health promotion and disease prevention. In: Raczynski JM, DiClemente RJ, editors. Handbook of health promotion and disease prevention. Boston, MA: Springer, 1999; p. 3-9.

36. Sithole HL. Ecological considerations for intervention strategy in the development of eye health promotion policy in South Africa. Afr Vision Eye Health. 2015;74:a314. https://doi.org/10.4102/aveh.v74i1.314 